\title{
Comparative study of either sufentanil or morphine added to a mixture of lignocaine and bupivacaine versus a mixture of lignocaine and bupivacaine alone in brachial plexus block
}

\author{
*Dr Mervat M. El Mously. ** Hossam M. Kandeel \\ Anaesthesia \& ICU* Orthopedic department**
}

\begin{abstract}
This study evaluates the peripheral opioid analgesia by comparing the effects from the addition of two types of opioids, morphine or sufentanil combined with a mixture of lignocaine $1 \%$ and of bupivacaine $0.5 \%$ with adrenaline $1: 200.000$ to the same mixture of lignocaine, bupivacaine and adrenaline alone for patients underwent elective surgery of the forearm and hand under axillary brachial plexus block.

The patients were divided into 3 equal groups, control (c) morphine (m) and sufentanil (s) groups. We evaluated onset of sensory block than postoperative mean arterial blood pressure (M.A.B.P), heart rate (HR), pain severity (V.A.S), time of first request of analgesia (T.F.R.A) and adverse effects. Our results showed that there were no significant differences on the onset of sensory block between (c), (m) \& (s) groups. As regards the M.A.B.P and HR, there were significant increase in (c) group compared to $(\mathrm{m})$ and $(\mathrm{s})$ groups at $(7-7.5 \mathrm{hrs})$ and significant increase in $(\mathrm{m})$ group compared to (c)and (s)groups at (8-9 hrs) and in (s) group compared to (c) and (m) group at $(11-12 \mathrm{hrs})$ postoperatively. This was due to the experience of pain at these times. After that (iv) morphine were given to abolish the postoperative pain untile the end of the study. Concerning the postoperative pain severity, the results showed that both $(\mathrm{m})$ and (s) groups had significant increase of analgesia as it showed lowest pain scores compared to (c) group, and in (s) group compared to (m) group, using visual analogue scale (V.A.S).

Time of first request of analgesia was delayed markedly in (s) group than (m) group and eventually (c) group. The adverse effects were greater with (m) group compared to (c) and (s) group while it was similar between (c) \& (s) group.
\end{abstract}

\section{Introduction}

Regional techniques through bloc king the input of noxious stimuli can reduce the stress of surgery as well as depression of the cardiac and respira tory systems produced by general anae sthesia and improve outcome in highrisk patients ${ }^{(1)}$. Opioids are most commonly delivered by oral, intramuscular, subcutaneous, intravenous, epidural and intrathecal routes, the identification of the peripheral opioids may be effective when used locally ${ }^{(2)}$.
Recently, opioid receptors have been discovered on immune cells sympathetic nerve fibers and peripheral neurons ${ }^{(3)}$. Peripheral analgesic effects of opioids may improve regional anae sthesia without centrally mediated side effects $^{(4)}$. Peripheral opioid receptors on primary afferents may be physiolo gically significant in that they may represent targets for endogenous opio ids, immuno-histochemical and bioche mical data indicate the existence of 
pro-dynorphine and pro-enkephaline derived opioid peptides in primary sensory neurons ${ }^{(5)}$.

Several authors has investigated the efficacy of injecting opioids into the brachial plexus sheath but the results remain inconclusive . as they ranged from improved quality of anaesthesia and postoperative analgesia to no effect. So we tried in our study to evaluate the effects of adding two different types of opioids as morphine and sufentanil to a mixture of local anaesthestics as ligno caine and bupivacaine versus the same mixture of the local anaesthestics alone for patients underwent elective upper extremity surgery for forearm and hand via the axillary approach of brachial plexus block.

\section{Material and methods}

The study was carried out as a single blind randomized controlled pro spective study of (60)patients of both sex , age ranged from 20 to 60 yrs., ASA $1 \& 11$, underwent elective upper extremity surgery for forearm and hand surgeries recruited from surgery and orthopedic departments . Patients with past history of allergy to local anaesth etics or opioids, peripheral neuropathy and signs of inflamation at the site of block were excluded. Informed consent was obtained from all the patients.

Patients were divided to three equal groups by simple randomization $\{20$ patients / group $\}$ and every patient has axillary brachial plexus block .

Group(1): \{lignocaine and bupiva caine control \{c\} group [N=20 patients] Every patient was given a mixture of 1 $\mathrm{mg} / \mathrm{kg}$ bupivacaine $0.5 \%$ and $2 \mathrm{mg} / \mathrm{kg}$ lignocaine $1 \%$ with 1:200000 adrenaline
Group(2): $\{$ morphine $\}\{\mathrm{m}\}$ group $[\mathrm{N}=20$ patients].Every patient was given a mixture of $1 \mathrm{mg} / \mathrm{kg}$ bupivacaine $0.5 \%$ and $2 \mathrm{mg} / \mathrm{kg}$ lignocaine $1 \%$ with 1:200000 adrenaline combined with morphine $(75 \mathrm{ug} / \mathrm{kg})$

Group(3): $\{$ sufentanil $\}\{\mathrm{s}\}$ group $[\mathrm{N}=20$ patients].Every patient was given a mixture of $1 \mathrm{mg} / \mathrm{kg}$ bupivacaine $0.5 \%$ and $2 \mathrm{mg} / \mathrm{kg}$ lignocaine $1 \%$ with 1:200000 adrenaline combined with sufentanil $(0.2 \mathrm{ug} / \mathrm{kg})$.

In all cases ,an 18 or 20 gauge (i.v) cannula was inserted in to the contra-lateral arm and 3-5mg(i.v) mida zolam was given as a sedation before the axillary brachial plexus block. Sensory block was assessed every 5 minutes from the time of injection of either local anaesthetics alone or comb ined with opioids by using pin-prick on a three point scale [ normal,Improved or absent] and the time of onset of sensory block was recorded.During surgery,all patients were received an (i.v) infusion of lactated ringer solution at a rate of 5$7 \mathrm{ml} / \mathrm{kg} / \mathrm{hr}$.

Pain intensity was assessed post operatively by (V.A.S) graded from 0 10 where $(0)$ represent no pain at all while (10) represented the worst possible pain. V.A.S was done imme diately after surgery $(0 \mathrm{hr})$ and hourly for the first $6 \mathrm{hrs}$ postoperatively and from 6-12 every half an hour then every 6 hours for the remainder of the time. Mean arterial blood pressure (M.A.B.P), heart rate, (T.F.R.A) and side effects were recorded when present at any time and at the same interval. If additional analgesics were needed postoperatively, morphine $15-40 \mathrm{ug} / \mathrm{kg}$ iv was given.

Statistical analysis was done using (t) test and chi-square test. 
Comparative study of either sufentanil....

\section{Results}

Table (1) : Evaluation of onset of sensory block with axillary brachial plexus block in $(\mathrm{c}),(\mathrm{m})$ and $(\mathrm{s})$ groups (mean $\pm \mathrm{SD})$

\begin{tabular}{|l|c|c|c|}
\hline $\begin{array}{l}\text { Onset of sensory block } \\
\text { [Absence of response to pin - } \\
\text { prick in minutes]. [mean } \pm \text { S.D] }\end{array}$ & $\begin{array}{c}\text { Control } \\
\text { (c) group }\end{array}$ & $\begin{array}{c}\text { Morphine } \\
(\mathrm{m}) \text { group }\end{array}$ & $\begin{array}{c}\text { Sufentanil } \\
\text { (s) group }\end{array}$ \\
\cline { 2 - 4 } & $20.0 \pm 0.81$ & $20 \pm 0.80$ & $20 \pm 0.78$ \\
\hline
\end{tabular}

$\mathrm{P}$ is significant if $<0.05$

P1 for comparison of (c) with (s) group.

$$
\begin{aligned}
& \mathrm{P} 1=0.10 \\
& \mathrm{P} 2=0.10 \\
& \mathrm{P} 3=0.10
\end{aligned}
$$$$
\text { P3 for comparison of (m) with (s) group. }
$$

*Means significant

Table (2): comparison of mean arterial blood pressure with axillary plexus block in (c), $(\mathrm{m})$ and (s) groups (mean $\pm \mathrm{SD})$.

\begin{tabular}{|l|c|c|c|c|c|c|}
\hline M.A.B.P time & $\begin{array}{c}\text { Control } \\
\text { group }(\mathbf{c})\end{array}$ & $\begin{array}{c}\text { Morphine } \\
\text { (m) group }\end{array}$ & $\begin{array}{c}\text { Sufentanil } \\
\text { (s) group }\end{array}$ & P1 & P2 & P3 \\
\hline 0 hr (at recovery) & $96.90 \pm 0.82$ & $96.91 \pm 1.07$ & $97.08 \pm 1.01$ & 0.10 & 0.10 & 0.10 \\
1 hr postoperative & $96.81 \pm 1.02$ & $97.83 \pm 0.83$ & $96.91 \pm 0.84$ & 0.10 & 0.10 & 0.10 \\
2 hrs. & $96.75 \pm 0.97$ & $96.84 \pm 0.92$ & $96.90 \pm 1.80$ & 0.10 & 0.10 & 0.10 \\
3 & $97.31 \pm 1.03$ & $96.78 \pm 1.02$ & $97.87 \pm 0.56$ & 0.10 & 0.10 & 0.10 \\
4. & $96.12 \pm 1.09$ & $97.06 \pm 1.14$ & $97.65 \pm 1.01$ & 0.10 & 0.10 & 0.10 \\
5 & $96.76 \pm 0.56$ & $97.90 \pm 1.00$ & $96.99 \pm 0.97$ & 0.10 & 0.10 & 0.10 \\
6 & $96.98 \pm 0.93$ & $97.30 \pm 0.85$ & $97.90 \pm 1.30$ & 0.10 & 0.10 & 0.10 \\
7 & $110.85 \pm 3.31$ & $96.99 \pm 0.89$ & $96.80 \pm 1.01$ & $0.01^{*}$ & $0.01^{*}$ & 0.10 \\
7.5 & $105.88 \pm 3.95$ & $96.80 \pm 0.93$ & $97.11 \pm 0.90$ & $0.01^{*}$ & $0.01^{*}$ & 0.10 \\
8 & $97.83 \pm 0.90$ & $103.92 \pm 2.56$ & $97.36 \pm 0.89$ & 0.10 & $0.01^{*}$ & $0.01^{*}$ \\
8.5 & $96.99 \pm 0.94$ & $101.89 \pm 2.62$ & $97.48 \pm 0.58$ & 0.10 & $0.01^{*}$ & $0.01^{*}$ \\
9 & $97.79 \pm 1.05$ & $100.96 \pm 2.96$ & $97.32 \pm 0.62$ & 0.10 & $0.01^{*}$ & $0.01^{*}$ \\
9.5 & $97.80 \pm 1.02$ & $96.75 \pm 1.86$ & $96.96 \pm 0.98$ & 0.10 & 0.10 & 0.10 \\
10 & $97.81 \pm 0.86$ & $97.01 \pm 1.92$ & $97.45 \pm 0.73$ & 0.10 & 0.10 & 0.10 \\
$10 . .5$ & $95.97 \pm 0.93$ & $96.69 \pm 1.91$ & $97.98 \pm 0.98$ & 0.10 & 0.10 & 0.10 \\
11 & $97.75 \pm 0.81$ & $97.03 \pm 0.98$ & $110.86 \pm 2.69$ & $0.01^{*}$ & 0.10 & $0.01^{*}$ \\
11.5 & $95.92 \pm 1.23$ & $96.82 \pm 0.73$ & $108.82 \pm 2.81$ & $0.01^{*}$ & 0.10 & $0.01^{*}$ \\
12 & $97.80 \pm 0.88$ & $96.90 \pm 0.98$ & $105.89 \pm 2.88$ & $0.01^{*}$ & 0.10 & $0.01^{*}$ \\
18 & $95.78 \pm 0.72$ & $96.75 \pm 1.74$ & $98.01 \pm 1.20$ & 0.10 & 0.10 & 0.10 \\
24 & $94.98 \pm 1.93$ & $96.86 \pm 1.50$ & $97.93 \pm 1.01$ & 0.10 & 0.10 & 0.10 \\
30 & $97.82 \pm 0.86$ & $97.03 \pm 1.09$ & $97.85 \pm 0.89$ & 0.10 & 0.10 & 0.10 \\
36 & $96.48 \pm 0.79$ & $97.00 \pm 0.93$ & $98.01 \pm 0.97$ & 0.10 & 0.10 & 0.10 \\
42 & $94.39 \pm 1.62$ & $96.83 \pm 0.79$ & $97.94 \pm 0.87$ & 0.10 & 0.10 & 0.10 \\
48 & $97.87 \pm 1.09$ & $96.91 \pm 0.86$ & $97.86 \pm 0.36$ & 0.10 & 0.10 & 0.10 \\
\hline
\end{tabular}


Dr Mervat M. El Mously \& Hossam M. Kandeel

Table (3): comparison of heart rate (H.R) changes with axillary plexus blocks in (c), (m) and $(\mathrm{s})$ groups (beat/minutes, mean $\pm \mathrm{SD})$.

\begin{tabular}{||l|c|c|c|c|c|c|}
\hline \hline Time of H.R & $\begin{array}{c}\text { Control }(\mathbf{c}) \\
\text { group }\end{array}$ & $\begin{array}{c}\text { Morphine } \\
(\mathbf{m}) \text { group }\end{array}$ & $\begin{array}{c}\text { Sufentanil }(\mathbf{s}) \\
\text { group }\end{array}$ & $\mathbf{P 1}$ & P2 & P3 \\
\hline $0 \mathrm{hr}$ at recovery & $75.61 \pm 3.65$ & $75.21 \pm 3.30$ & $75.69 \pm 3.50$ & 0.10 & 0.10 & 0.10 \\
$1 \mathrm{hr}$ & $75.058 \pm 3.59$ & $75.00 \pm 4.06$ & $75.63 \pm 3.49$ & 0.10 & 0.10 & 0.10 \\
$2 \mathrm{hrs}$ & $75.60 \pm 3.62$ & $74.91 \pm 4.11$ & $74.92 \pm 4.08$ & 0.10 & 0.10 & 0.10 \\
3 & $74.89 \pm 4.56$ & $75.58 \pm 3.69$ & $74.85 \pm 4.03$ & 0.10 & 0.10 & 0.10 \\
4 & $74.91 \pm 4.38$ & $74.86 \pm 4.10$ & $75.59 \pm 3.63$ & 0.10 & 0.10 & 0.10 \\
5 & $75.53 \pm 3.50$ & $75.51 \pm 3.67$ & $75.67 \pm 3.58$ & 0.10 & 0.10 & 0.10 \\
6 & $75.61 \pm 3.53$ & $74.89 \pm 4.13$ & $75.64 \pm 3.52$ & 0.10 & 0.10 & 0.10 \\
7 & $90.90 \pm 3.11$ & $74.72 \pm 3.28$ & $74.98 \pm 4.02$ & $0.01^{*}$ & $0.01^{*}$ & 0.10 \\
7.5 & $90.78 \pm 3.32$ & $74.93 \pm 3.17$ & $75.64 \pm 3.49$ & $0.01^{*}$ & $0.01^{*}$ & 0.10 \\
8 & $75.61 \pm 3.70$ & $88.29 \pm 4.41$ & $75.58 \pm 3.39$ & 0.10 & $0.001^{*}$ & $0.01^{*}$ \\
8.5 & $75.58 \pm 3.72$ & $87.31 \pm 3.87$ & $74.89 \pm 4.11$ & 0.10 & $0.01^{*}$ & $0.01^{*}$ \\
9 & $75.62 \pm 3.64$ & $88.42 \pm 3.78$ & $75.54 \pm 3.51$ & 0.10 & $0.001^{*}$ & $0.01^{*}$ \\
9.5 & $75.53 \pm 3.69$ & $67.11 \pm 3.58$ & $74.87 \pm 4.20$ & 0.10 & 0.10 & 0.10 \\
10 & $75.64 \pm 3.73$ & $76.62 \pm 3.92$ & $75.63 \pm 3.50$ & 0.10 & 0.10 & 0.10 \\
10.5 & $75.41 \pm 3.02$ & $76.02 \pm 3.18$ & $74.86 \pm 3.99$ & 0.10 & 0.10 & 0.10 \\
11 & $75.30 \pm 3.31$ & $76.78 \pm 3.68$ & $89.78 \pm 3.52$ & $0.01^{*}$ & 0.10 & $0.01^{*}$ \\
11.5 & $75.45 \pm 3.38$ & $75.70 \pm 3.65$ & $86.32 \pm 2.67$ & $0.01^{*}$ & 0.10 & $0.01^{*}$ \\
12 & $75.90 \pm 2.01$ & $75.68 \pm 3.76$ & $87.45 \pm 2.18$ & $0.01^{*}$ & 0.10 & $0.01^{*}$ \\
18 & $74.51 \pm 3.57$ & $75.52 \pm 3.58$ & $75.61 \pm 3.48$ & 0.10 & 0.10 & 0.10 \\
24 & $75.49 \pm 3.49$ & $74.48 \pm 4.30$ & $75.65 \pm 3.53$ & 0.10 & 0.10 & 0.10 \\
30 & $75.58 \pm 2.11$ & $75.51 \pm 3.42$ & $75.71 \pm 3.42$ & 0.10 & 0.10 & 0.10 \\
36 & $74.99 \pm 3.38$ & $74.79 \pm 4.08$ & $75.72 \pm 3.50$ & 0.10 & 0.10 & 0.10 \\
42 & $74.97 \pm 3.51$ & $75.86 \pm 3.68$ & $74.89 \pm 4.38$ & 0.10 & 0.10 & 0.10 \\
48 & $74.92 \pm 3.75$ & $74.91 \pm 4.48$ & $75.59 \pm 3.51$ & 0.10 & 0.10 & 0.10 \\
\hline
\end{tabular}

Table (4): comparison of postoperative pain severity changes using visual analogue scale (V.A.S) with axillary plexus block in (c), (m) and (s) groups (mean $\pm \mathrm{SD}$ ).

\begin{tabular}{||l|l|l|l|l|l|l||}
\hline Time of V.A.S & $\begin{array}{l}\text { Control (c) } \\
\text { group }\end{array}$ & $\begin{array}{l}\text { Morphine }(\mathrm{m}) \\
\text { group }\end{array}$ & $\begin{array}{l}\text { Sufentanil }(\mathrm{s}) \\
\text { group }\end{array}$ & $\mathrm{P} 1$ & $\mathrm{P} 2$ & $\mathrm{P} 3$ \\
\hline $0 \mathrm{hr}$ at recovery & $0.26 \pm 0.96$ & $0.03 \pm 1.05$ & $0.08 \pm 0.09$ & 0.10 & 0.10 & 0.10 \\
$1 \mathrm{hr}$ & $0.70 \pm 0.80$ & $0.21 \pm 0.90$ & $0.26 \pm 0.19$ & 0.10 & 0.10 & 0.10 \\
$2 \mathrm{hrs}$ & $0.30 \pm 1.20$ & $0.20 \pm 1.03$ & $0.34 \pm 0.21$ & 0.10 & 0.10 & 0.10 \\
3 & $0.48 \pm 1.01$ & $0.36 \pm 0.87$ & $0.31 \pm 0.17$ & 0.10 & 0.10 & 0.10 \\
4 & $0.80 \pm 0.37$ & $0.18 \pm 0.78$ & $0.89 \pm 0.65$ & 0.10 & 0.10 & 0.10 \\
5 & $0.90 \pm 1.00$ & $0.87 \pm 0.73$ & $0.90 \pm 0.39$ & 0.10 & 0.10 & 0.10 \\
6 & $1.01 \pm 0.90$ & $0.96 \pm 0.55$ & $0.98 \pm 0.87$ & 0.10 & 0.10 & 0.10 \\
7 & $6.32 \pm 1.01$ & $1.01 \pm 0.75$ & $0.87 \pm 0.83$ & $0.001^{*}$ & $0.001^{*}$ & 0.10 \\
7.5 & $6.29 \pm 0.99$ & $0.92 \pm 0.63$ & $0.97 \pm 0.90$ & $0.001^{*}$ & $0.001^{*}$ & 0.10 \\
8 & $0.38 \pm 0.81$ & $5.82 \pm 1.90$ & $1.01 \pm 0.07$ & 0.10 & $0.001^{*}$ & $0.001^{*}$ \\
8.5 & $0.90 \pm 0.79$ & $5.80 \pm 1.75$ & $0.90 \pm 0.58$ & 0.10 & $0.001^{*}$ & $0.001^{*}$ \\
9 & $0.39 \pm 0.88$ & $5.79 \pm 1.51$ & $0.93 \pm 0.96$ & 0.10 & $0.001^{*}$ & $0.001^{*}$ \\
9.5 & $0.67 \pm 0.63$ & $0.98 \pm 0.05$ & $0.40 \pm 0.26$ & 0.10 & 0.10 & 0.10 \\
10 & $0.49 \pm 0.35$ & $1.67 \pm 0.70$ & $1.02 \pm 0.53$ & 0.10 & 0.10 & 0.10 \\
10.5 & $0.31 \pm 0.42$ & $1.72 \pm 0.83$ & $1.06 \pm 0.60$ & 0.10 & 0.10 & 0.10 \\
11 & $0.34 \pm 0.39$ & $1.40 \pm 0.66$ & $6.70 \pm 1.02$ & $0.001^{*}$ & 0.10 & $0.001^{*}$ \\
11.5 & $0.52 \pm 0.44$ & $1.29 \pm 0.52$ & $6.71 \pm 1.00$ & $0.001^{*}$ & 0.10 & $0.001^{*}$ \\
12 & $0.39 \pm 0.73$ & $0.98 \pm 1.96$ & $6.69 \pm 0.99$ & $0.001^{*}$ & 0.10 & $0.001^{*}$ \\
18 & $0.97 \pm 0.86$ & $0.28 \pm 0.87$ & $0.98 \pm 1.75$ & 0.10 & 0.10 & 0.10 \\
24 & $0.95 \pm 0.82$ & $0.32 \pm 0.79$ & $1.11 \pm 0.08$ & 0.10 & 0.10 & 0.10 \\
30 & $0.81 \pm 0.45$ & $0.58 \pm 0.98$ & $0.89 \pm 0.99$ & 0.10 & 0.10 & 0.10 \\
36 & $0.91 \pm 0.58$ & $0.94 \pm 0.85$ & $0.90 \pm 1.01$ & 0.10 & 0.10 & 0.10 \\
42 & $1.01 \pm 0.09$ & $0.85 \pm 0.98$ & $1.09 \pm 0.11$ & 0.10 & 0.10 & 0.10 \\
48 & $0.88 \pm 0.78$ & $1.03 \pm 1.04$ & $1.10 \pm 0.09$ & 0.10 & 0.10 & 0.10 \\
\hline
\end{tabular}


Comparative study of either sufentanil....

Table (5): Evaluation of adverse effects with axillary plexus block in(c),(m) and (s) groups:

\begin{tabular}{|l|c|c|c|}
\hline The adverse effects & Control (c) group & Morphine (m) group & Sufentanil (s) group \\
\hline Nausea. & 0 & 2 & 1 \\
\hline Vomiting. & 1 & 2 & 0 \\
\hline Urine retention & 0 & 2 & 0 \\
\hline $\begin{array}{l}\text { Total number of } \\
\text { adverse effects with } \\
\text { [ mean } \pm \text { S.D ] }\end{array}$ & $1=1.0 \pm 0.85$ & $6=4.0 \pm 2.92$ & $1=1.0 \pm 0.85$ \\
\hline
\end{tabular}

$\mathrm{P} 1=0.10$

$\mathrm{P} 2=0.002$

$\mathrm{P} 3=0.002$

Table (6). Time of first request of analgesia (T.F.R.A.)with the axillary plexus block in $(\mathrm{c}),(\mathrm{m})$ and $(\mathrm{s})$ groups

\begin{tabular}{|c|c|c|c|}
\hline $\begin{array}{l}\text { Time of first request of analgesia } \\
\text { (T.F.R.A) }\end{array}$ & $\begin{array}{l}\text { Control (c) } \\
\text { group }\end{array}$ & $\begin{array}{l}\text { Morphine }(\mathrm{m}) \\
\text { group }\end{array}$ & $\begin{array}{l}\text { Sufentanil (s) } \\
\text { group }\end{array}$ \\
\hline $0 \mathrm{hr}$ (at recovery room) & 0 & 0 & 0 \\
\hline $1 \mathrm{hr}$ & 0 & 0 & 0 \\
\hline 2 & 0 & 0 & 0 \\
\hline 3 & 0 & 0 & 0 \\
\hline 4 & 0 & 0 & 0 \\
\hline 5 & 0 & 0 & 0 \\
\hline 6 & 0 & 0 & 0 \\
\hline 7 & 8 & 0 & 0 \\
\hline 7.5 & 5 & 0 & 0 \\
\hline 8 & 2 & 5 & 0 \\
\hline 8.5 & 1 & 4 & 0 \\
\hline 9 & 1 & 4 & 0 \\
\hline 9.5 & 0 & 0 & 0 \\
\hline 10 & 1 & 1 & 0 \\
\hline 10.5 & 0 & 1 & 0 \\
\hline 11 & 1 & 1 & 6 \\
\hline 11.5 & 0 & 1 & 5 \\
\hline 12 & 0 & 1 & 4 \\
\hline 16 & 1 & 0 & 0 \\
\hline 18 & 0 & 1 & 1 \\
\hline 24 & 0 & 0 & 1 \\
\hline 27 & 0 & 1 & 0 \\
\hline 30 & 0 & 0 & 2 \\
\hline 36 & 0 & 0 & 1 \\
\hline 24 & 0 & 0 & 0 \\
\hline 48 & 0 & 0 & 0 \\
\hline Mean \pm S.D. (hrs.) & $9.62 \pm 1.86$ & $20.0 \pm 3.85$ & $25.3 \pm 6.71$ \\
\hline
\end{tabular}




\section{Discussion}

This work was designed to evaluate the peripheral opioids analgesia by comparing the effects resulted from the addition of either sufentanil or morph ine to a mixture of lignocaine and bupi vacaine to the same mixture of ligno caine and bupivacaine alone in the axil lary brachial plexus block for elective upper extremity surgery.

As regard the time of onset of sensory block, table (1), the results of our study showed no significant differ rence of axillary brachial plexus block with L.As or combined with morphine or sufentanil. This result agree with that of Bouaziz et al.,2000 ${ }^{(6)}$ who concluded from their study that the addition of sufentanil did not increase the onset of the block compared to the Local anaethetics ( L. As) alone.

In agreement with our results, Flory et al.,1995 ${ }^{(7)}$, who proved that no differences in the onset of sensory block between L.As, alone or L.As, with morphine .On the other hand, Simon et al., $1999^{(8)}$, who showed that the mean onset time of sensory block of lidoc aine was approximately 10 minutes, this difference of onset of sensory block compared to that of our results can be attributed to the high dose $(600 \mathrm{mg})$ used of lidocaine. This difference of onset of sensory block can also be explained by Gauver et al.,1996 ${ }^{(9)}$, who reported that the higher doses of axillary brachial plexus L.As.may possible act spinally rather than locally by several mechani sms as it may transported into the epid ural space or by retrograde axonal transport in addition to their diffusion along the nerve.

As regards the (M.A.B.P) \& HR.at (7-7.5) hrs. ,(table 2\&3), the signif icant increase in (c) group compared to $(\mathrm{s}) \&(\mathrm{~m})$ groups attributed to the feeling of $(65 \%)$ of patient from pain while (m)\&(s) still have pronounced analgesia This is in agreement with Peter et al.,1989 ${ }^{(10)}$, who reported that painful stimuli in moderate form stimulate the vasoconstrictor center(V.C.C) in the $4^{\text {th }}$ ventricle in the medulla oblongata thro ugh the hypothalamus leading to vasoc onstriction and increased blood press ure. The increase in H.R.in (c) group can be explained by , Ness and Gebhart $2000^{(11)}$ who reported that painful impulses passes to the thalamus than to the posterior hypothalamic nuclei with control the sympathetic system leading to stimulation of cardiac accelerating center (C.A.C) and tachycardia .

At (8- 9) hrs. the (M.A.B.P. \& H.R.) in (m) group was increased signi ficantly compared to (c) \& (s) group may be resulted from the start of exper ience of pain as explained by Gerhamd et al $1999^{(12)}$ who reported that non specific stimuli out side the cardio vascular system are able to influence the circulation and increase (M.A.B.P.), this include pain and cold temperature. Wilso and Lamer , $1999^{(13)}$, reported that activation of pain receptors with painful stimuli cause direct stimulation of the cardiac center in the medulla that lead to increase rhythmicity of S.A. node, the (H.R.) and forces of ventri cular contraction .

At $(11,11.5$ and 12) hrs. postoperatively, the significant increase in (M.A.B.P. \& H.R.) in (s) group com pared to $(\mathrm{c})$ and $(\mathrm{m})$ groups attributed to experience of pain in $(75 \%)$ of $(\mathrm{s})$ group. After that there is no difference due to the suplimental (iv) morphime that abolish the postoperative pain in all groups .

Flack et al.,2000 ${ }^{(14)}$,stated that sufentanil provides better blockade of the classical haemodynamic response to surgical stimuli.Thomson et al., 
$2000^{(15)}$,reported that sufentanil lowers catecholamine release during the day case surgical procedures under either regional or general anaethasia as their results showed that the hypodynamic reactions including (H.R. and M.A.B.P) pattern were naturalized.

Concerning the postoperative pain severity evaluation, and (T.F.R.A) ( table 4\&6 ), our results showed a markedly significant differences of either (s) and (m) groups compared to the (c) group, and (s) group compared to (m ) group. visual analogue scale was high at (7-7.5) hrs , (8 - 9$)$ hrs (11- 12$)$ hrs in groups (c ), (m ) and (s) groups respectively all these timing corresp onding to T. F. R.A as the patients started to complain of postoperative pain and suplemental (iv ) morphine was given .The reason for the differences in postoperative anagesia between the (c) group compared to either (s) or (m) groups can be attributed to the contribution of both (s) and $(\mathrm{m})$ in the peripheral opioids analgesia by interaction with the peripheral opioid receptors that are numerous in the peripheral ending and axons of primary afferent sensory nerve fibers, while L.As. lidocaine and bupivacaine alone lack the properties of interaction with the opioid receptors either peripherally or centrally ${ }^{(16)}$. Our results is in agreement of Bazin et al.,1997 $7^{(17)}$ who reported significant decrease in postoperative analgesia in lignocaine and bupivacaine group compared to the opioids with the L.As. in their block.

In contrary to our result, Bullingham et al.,1983 ${ }^{(18)}$, who failed to obtain any pain relief with perineural morphine in patients following ankle surgery,they attributed their results to the fact that a nerve stimulator was not used to locate the appropriate nerve, so morphine may not have been deposited accurately perineurally around the nerves concerned, in addition, the anatomical structure difference of knee joint with brachial plexus in our study may play a role.

The significant increase in postoperative analgesia between (s) and (m) groups can be attributed to that opioids have differences in their affinities for the opioids receptors ${ }^{(19)}$. This can be supported by Paterson $\boldsymbol{e t}$ al., $1993^{(20)}$, who indicated that fentanyl and morphine have similar affinities for $\mu(\mathrm{mu})$ receptors but pethedine and also fentanyl have much greater affinity for delta and kappa receptors.In addition, Leyson and Gommeron 2001 ${ }^{(21)}$ reported that sufentanil has a high affinity for sterospecific binding sites$\mu(\mathrm{mu})$-receptors and it shown 8times stronger binding affinity to $\mu(\mathrm{mu})$ than fentanyl,this high affinity cause slow dissociation from $\mu(\mathrm{mu})$ rece -ptors ,also sufentanil shows selective analgesic action which is only mediated by the same $\mu(\mathrm{mu})$ receptors.Another factor which should be taken into consideration is the much greater lipid solubility of fentanyl and pethidine compred with morphine this allow greater distribution at the site of action as afferent nociceptive fibers are surrounded by a layer of myelin which presents a significant obstacle to water soluble agents ${ }^{(22)}$.As sufentanil is more lipid soluble than fentanyl, approx imately 5-10 times more potent than fentanyl,thus it can be superior to their effect on nerve fibers compared to morphine.Thus from our results, it was shown that peripheral adminstration of opioids as sufentanyl or morphine had been suggested a mean of improving regional block as axillary brachial plexus block through their interaction with the peripheral opioid receptors, this can be explained by Gormley et al., $1996^{(23)}$,who reported that peripheral opioid receptors are through produce anti-nociception in variety of ways. 
First, A local anaethetic action on the excitability of nerve terminals and the propagation of nerve impulses, this can be achieved by two mechanisms either Involve an early decrease in sodium conductance and a delayed decrease in potassium conductance, this effect is not reversed by naloxone and have been demonstrated on the peripheral nerves with fentanyl and sufentanil, and improved nerve impulses conduction is seen in high concentration, or L.As. action is reversible by naloxone and involves a decrease in sodium conduc tance alone, this action occurs at lower opioid concentration.

Second Other mechanisms of action of peripheral opioid receptors involve inhibition of release of substance-P from peripheral terminals of primary afferent neuron.

As regard to the (T.F.R.A), our results were in agreement with that of Bazin et al.,1997 ${ }^{(17)}$. who found that the addition of opioids to a mixture of bupivacaine and lignocaine in brachial plexus block double the duration of postoperative pain relief, also the more lipophilic, the longer the effect seems to last. In contrary to our results, Gormley et al.,1996 ${ }^{(13)}$, who studied the peripheral analgesic effects of lidocaine , adrenaline and alfentanil compared to liodcaine and adrenaline alone .Their study showed that (T.F.R.A) in alfentanil group was $3.8 \mathrm{hrs}$. to $6.6 \mathrm{hrs}$ and in lidocaine only from $2.6 \mathrm{hrs}$. to $8.4 \mathrm{hrs}$. The difference in our (c) group to that of lidocaine alone that we used a mixture of «2» different types of L.As. as bupivacaine and lidocaine with adrenaline .Bupivacaine, as reported by Pinock et al., $1997^{(24)}$, has a slow onset in the peripheral nerve block but with long duration while lidocaine alone is more faster in onset compared to bupivacaine but with meduim duration.The difference of (T.F.R.A)in alfentanil group added to lidocaine compared with (s), (m) groups of our study not only to the use of bupivacaine in our study while its absence in alfentanil study but also to the alfentanil clearance as explained by Barash $\boldsymbol{e t}$ $\boldsymbol{a l} .2000^{(25)}$, who indicated that the greater decrease in alfentanil volume of distribution relative to the decrease in its clearance result in significantly short time. lorase et al., $1997^{(26)}$ stated that the dorsal roots of primary nerve fibers contain peripherel opioid receptors, particularly $\mathrm{M}$ - binding sites, this may improve the peripheral opioid analgesia compared to L.As effect on the nerve

As regard the adverse effects, the present study showed that there was higher incidence of nausea and vomiting (4 patients) of the $(\mathrm{m})$ group compared to (s) and (c) groups as P3 and P2 were statistically significant respectively. These adverse effcts can be attributed to the partial systemic resorption of opioids as reported by Bazin et al.1997 ${ }^{(17)}$ Barash et $\boldsymbol{a l} ., 1998^{(27)}$, who reported that emesis reflect opioid induced stimulation of the chemoreceptors trigger zone especially in ambulatory patients, suggesting a vestibular components. Our results showed that there were two patients of the total (m) group suffered from urine retention this result can be explained by:Stoeling et al., $1996^{(28)}$, who reported that morphine decrease the urethral and detruser muscle tone resulting in the possibility of urine retention. Only one patient of the (c) group suffered from nausea and vomiting,this can be explained by Andro et al., $1997^{(29)}$, who reported that nausea and vomiting can associated with severe pain that cause vagal affe rent which stimulate the vomiting center producing nausea and vomiting.

We concluded that the addition of opioids to a mixture of ( L. As ) as lignocaine and bupivacaine with the 
axillary brachial plexus block improved the quality of this type of regional block, expressed by the increased duration of postoperative pain relief, delayed of first time for analgesics request and decrease of supplemental analgesics compared with that of both local anaesthetics alone.

\section{References}

1.Yeager. M, Class. S, Neffpk. M. (1987): epidural anaesthesia and analgesia in high risk surgical patie nts, Anaesthesiology, 66: 239-36.

2.Raymound. R, Phlip. O,Kalso.E (1992): Management of pain. Clinical anaesthesia, 431.

3.Brose.R,Maier.C,Wedel. D(1991): Pain, clinical anaesthesia,. P 710.

4.Bourk.D,furman.W,Fink.R . (1993): Improved postoperative analgesia with morphine added to axillary block solution, anaesthesia, 5:114117.

5.Weine. E, Nohr. D and Hartechuh. V. (1988): Immunohistochemical evidence for a co-transmitter role of opioid peptides in primary sensory neurons. Brain Res., 74:189 -199.

6.Bouaziz. H, Kinirons. B,Macalou. $D$, Heck. $M$ and Laxenaire. M.(2000): Sufentanil does not prolong the duration of analgesia in a mepivacaine brachial plexus block, a dose response study. Anaesth. Analg. (90)2: 383 -387.

7.Flory. N,Van.G,Donald. F, Hoffmeyer. $P$ and Gamulin. $Z$. (1995): Dose the addition of morphine to brachial plexus block improve analgesia after shoulder surgery? . Br. Journal of anaeth., 75:23-26.

8.Simon. M, Vree. T, Gielen. M,Booij. $L$ and Lagerwerf. A.(1999):Similar motor block effects with different disposition kinetics between lidocaine and articaine in patients undergoing axillary brachial plexus block during day case surgery, International journal of clinical pharma-cology and therapeutics, 37(12):598-607.

9.Gauver. J, Sungelin. F, Batholome. $S$ and Dangoisse. M.(1996): The effects of higher doses of lidocaine, bupivacaine and mepivacaine on the onset and duration of anaesthesia and analgesia with axillary brachial plexus block, reg. Aneasth. 17:14850.

10. Peter. M.C, Dyal. C.G and Roy. E.S.(1989): Pain, Medical physiology, $4^{\text {th }}$. edit. P:176.

11. Ness. T and Gebhart. G. (2000): Visceral pain: A review of experiemental pain studies. Annu. Rev. Physiol, (41): 167-234.

12. Gerhand. T,Mutscher. $C$ and Vaupel. K.(1999): Human anatomy, physiology and pathophysiology. 15edit. Ch. 5,p: 315-320.

13. Wilso. $R$ and Lamer. J.(1999): Pain mechanisms: Anatomy and physiology in : Practical manage ment of pain, Mosby year book.

14. Flack. J, Bloor. B, Kripke. B, Kripke. B, Warneck. C, Wong. D and Katz. R.(1997): Descriptive study of sufentanil effects with the surgical procedures under general and regional blocks in day case surgerys. Reg.Anaesth. (64):879.

15. Thomson. I, Hudson. R,Rosen bloom. $M$ and Meatheral. $R$. (2000): Descriptive study of sufen tanil effects with the surgical procedures under regional or general anaethesia in day case surgerys. (Abst) of the $5^{\text {th }}$.World Congress on pain, Hamburge, 227.

16. Wildsmith. J, Gissen. A and Sterly. S.(1991): Local anaesthetic in Clinical practice, Canadian anaest -hetists society journal, 35:201 -208

17. Bazin. J,Massoni. C, Bruelle. P, fenies. V and Schoeffler. P.(1997): 
the addition of opioids to local anaesthetics in brachial plexus block: The comparative effects of morphine, bupernorphine and sufen -tanil, Anaesthesia, (52): 858-862.

18. Bullingham. R, Sullivan. G, Mequary H,Evan. $P$ and Moore. A. (1983): Perineural injection of morphine fails to relive postop erative pain in humans. Anaesth. Analg. (62): 164-167.

19. Weine. E, Nohr. D and Hartschuh. W. (1988): Antinoci ceptive effects of $\mathrm{u}$ and $\mathrm{K}$-agonists are enhanced due to a peripheral opioid receptors- specific mecha nism. Prog. Brain. Res:189-99.

20. Paterson. S,Robson. $L$ and Kosterlitz. H. (1993): Opioids receptors and their roles in the analgeic mechanisms. Eur. J. Pharmacol. (93):179-183.

21. Leyson. $J$ and Gommeron. W. (2001): Properties of $3 \mathrm{H}$-sufentanil, a superior ligand for the u-opiate receptor, Arch. Int. Pharmacodyn.ther. 265-287.

22. Dubois. P, dewachter. $B$ and Massaut. J. (1988): Analgesic anaesthesia with fentanyl, sufentanil and morphine with coronary surgery, Ablind study, Acta. Pharmacol: 310-350.

23. Gormley. J, Murray. $T$ and Bower. S.(1996): Effect of the addition of alfentanil to Lignocaine during axillary brachial plexus anaesthesia, Br. J of anaesth. (76): 802805.

24. Pincock. C,Fisher. H,Jones. R and Rubin. A. (1997): Local anaesthetic drugs, peripheral nerve blockade. Ch. 14.P:120 -15.

25. Barash. P, Cullen. $B$ and Stoelting. R.(2000): Opioids, pharmacokinetics and pharmacod ynamics, Hand book of clinical anaesthesia. 137-148.

26. Lorase. S,Kim. $\mathbf{N}$ and Philip. $\mathbf{N}$. (1997): Effect of opioids and local anaesthetics on the central nervous system. Reg. Anaesth. 18:260-262.

27. Barash. J,Smith. S and Maickel. F. (1998): Opioids, clinical pharmac -ology and therapeutic management, $3^{\text {rd }}$. ediy.ch. 161,p:210-15.

28. Stoeling. C,Russel. L and Miller. R.(1996): Opioids, Basics of anaesthesia, $4^{\text {th }}$. Edit: 44-72.

29. Andro. T, Ronald. S, Robert. K.(1997): Gastrointestinal disorder, Cecil essential of medicine, vol. 1 : 256-257. 
Comparative study of either sufentanil....

دراسة مقارنة لكل من السوفنتانيل او المورفيين المضافين لخليط اللجنو كايين البيوبيفاكايين فى مقابل خليط اللجنو كابين البيوبيفاكين فقط في تخدير حزمة العض العصبية

\section{*. ميرفت محمد الموصيلى - - *. حسام محمد قنديل \\ *قسم التخدير والرعاية المركزة كلية الطب بنات. جامعة الازهر \\ ( ق قسم جر احة العظام بمعهد شلل الأطفال}

- كدف هذه الدراسة لمقارنة التأثير الناتج من إضافة الأدوية المخدرة بالإضافة لأدوية التخدير الموضعى

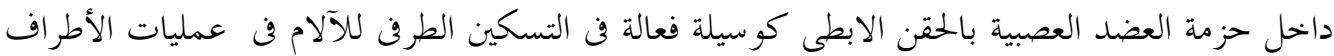
العليا بالمقارنة بحقن الأدوية المخدرة الموضعية فقط. - - وقد شملت الدراسة 60 مريضا تم تقسيمهم إلى ثلاثة بحاميع متساوية. البحموعة (الأولى) الضابطة(20) مريض تم إعطائهم خليط من البيو بيفاكيين واللجنو كايين بالإضافة إلى الادرناليين و البحموعة الثانية (20) مريضا تماني

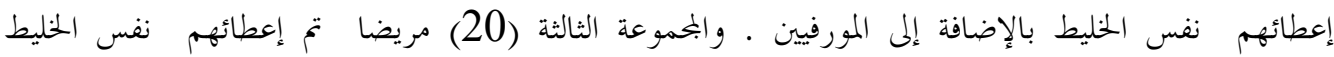
بالإضافة إلى السوفنتانيل - وقد تم تقييم بداية زوال الإحساس قبل الجراحة وقياس ضغط الدم الشريانى وضربات القلب وقياس شدة الألم

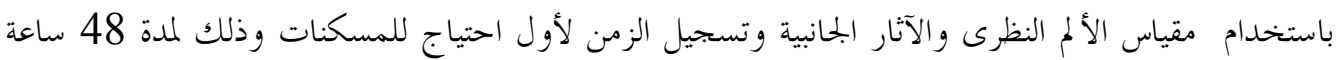
بعد العملية. - - وكانت نتائج البحث انه لا يوجد فرق بين البحموعات الثلاثة بالنسبة لبداية زوال الإحساس.

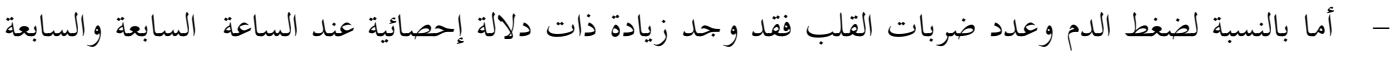
و النصف في البمموعة الضابطة وعند الساعة الثامنة والثامنة والنصف والتاسعة في المجموعة الثانية وعند الساعة

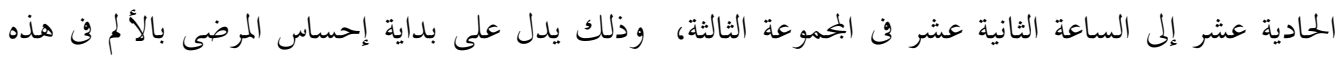

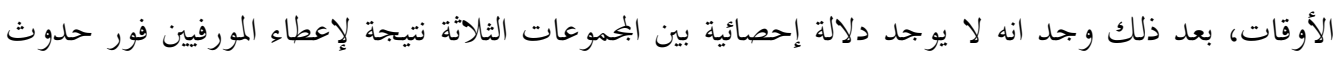

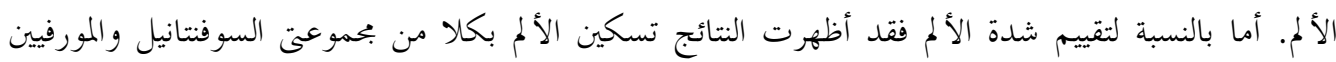

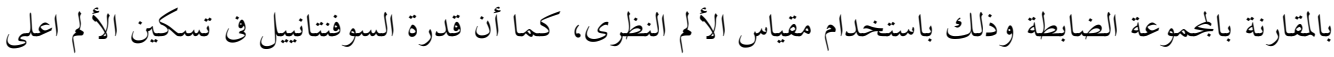
من المورفيين. - - ولقد كانت الأعراض الجانبية اكثر بلمموعة المروفيين عنها في بحموعتى السوفنتانييل والبحموعة الضابطة بينما تساوت الأعراض الجانبية في بحموعتي السوفتتانيل والضابطة.

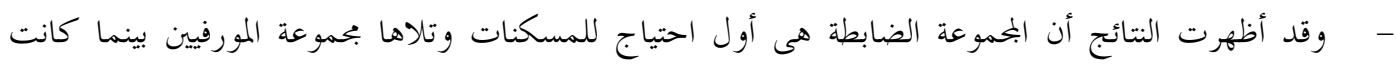

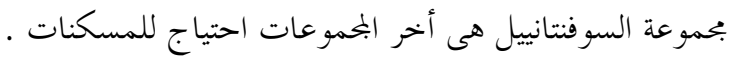

